\title{
VICTIMHOOD OF THE NATION AS A LEGALLY Protected Value in Transitional States - Poland as a Case Study
}

\author{
ALEKSANDRA GLISZCZYŃSKA-GRABIAS* , ANNA ŚLEDZIŃSKA-SIMON**
}

Memory is both a blessing and a curse for nations with history marked by tragedy. In a moment of catastrophe memory is the ultimate weapon for a nation, the very last bastion of national self-defence [....]. Such memory creates beautiful national myths and elevates the past; it beautifies the ugly; the sins of its own community are thus doomed to be forgotten. ${ }^{1}$

\section{INTRODUCTION}

The memory of the past is always vital for building national identity in transitional contexts. Yet, the preservation of a particular representation of the national history may lead not only to distortion of the selfidentification process, but also to distortion of rights protection. Taking Poland as a case study, we aim to explain mechanisms of using criminal laws for historical assessment and show instances when victimhood became a legally protected value used to justify limitations of free speech and academic research. We argue that the law criminalising defamation of the Polish Nation, and also the decision of the Polish Constitutional Tribunal, were symptoms of frustration and fear against opening and engaging in an honest public debate on recent history, which is necessary for establishing not only the fundamentals of transitional justice, but more importantly, for building mutual trust in a democratic society.

DOI: 10.1515/wrlae-2018-0004

* PhD; Assistant Professor, Poznań Human Rights Centre, Institute of Legal Studies of Polish Academy of Sciences.

** LLM, PhD, SJD; Assistant Professor, Department of Constitutional Law, Faculty of Law, Administration and Economics, Wroclaw University; anna.sledzinskasimon@uwr.edu.pl.

${ }^{1}$ Adam Michnik 'Żydowski problem z pamięcią' ('Jewish problem with the memory'), Gazeta Wyborcza, 28 April 2013. 


\section{SHAPING NATIONAL IDENTITY IN THE CONTEXT OF DEMOCRATIC TRANSITION}

The Constitution of Poland adopted in 1997 formally envisioned that the Nation is a political body comprised of Polish citizens ${ }^{2}$. Yet the notion of the Polish Nation as a Weberian community of sentiment prevailed in the Parliament when it criminalized public statements which suggested the participation of the Polish Nation in Communist and Nazi crimes. ${ }^{3}$ Although the legislative intent seemed to be benign (it is a generally legitimate aim to protect the national honour), the legislators have summarily assumed that neither the Polish Nation nor its individual members were involved in Communist and Nazi crimes. The disputed provision, challenged by many as contrary to freedom of speech and academic research, revealed a whole range of disturbing legal dilemmas concerning national identity in democratic transition. Among other things, it raised the question regarding the role of constitutional courts in shaping national memory. ${ }^{4}$

The Polish Constitutional Court (Trybunat Konstytucyjny, hereinafter 'TK') quashed the impugned provision exclusively on procedural grounds finding that the legislative procedure which led to its adoption was contrary to the Constitution. ${ }^{5}$ Taking into consideration the significance of the case, and its emotion-laden context, the position of the TK is very disappointing. Not only did it fail to elaborate on the importance of free speech in a democratic society, but also failed to explain the concept of national identity that may require searching for truth about the nation's past. Neither did the TK express its opinion about a broader issue of doing justice in posttotalitarian states which has to encompass both perpetrators and victims of totalitarianism. Yet, the TK found it necessary to remove the provision from the legal system, acting only as a guardian of the rule of law (limited to its procedural aspect), but lacked the courage to stand out as a guardian of substantive fundamental values enshrined in the Constitution. Seen in this light, the TK acted as a passive bystander, concerned only about the quality of the legislative process, instead of teaching the legislator about the

\footnotetext{
${ }^{2}$ A legal definition of the Nation can be found only in the Preamble of the Constitution. Although the Constitution adopted a demotic understanding of a nation that is based on citizenship, the concept of a nation that permeates the Constitution is not coherent. The Preamble refers to "the Polish Nation" and "the Motherland", following German and other Eastern European models, which give a clear priority to the pre-political loyalties derived from a common language, culture, ethnicity, or religion.

3 Article 37 of the Act of 18 October 2006 on the disclosure of information about documents of state security organs from the years 1944-1990 and their contents (the Lustration Act - ustawa z dnia 18 października $2006 \mathrm{r}$.

o ujawnianiu informacji o dokumentach organów bezpieczeństwa państwa z lat 1944-1990 oraz treści tych dokumentów (Official Journal [Dz.U.], no. 218, item 1592, 2006) incorporating Article 132a to the Criminal Code.

${ }^{4}$ See Kim Lane Scheppele, 'Constitutional Interpretation after Regimes of Horror' in Susanne Karstedt (ed), Legal Institutions and Collective Memories (Oxford: Hart Publishing 2009) 233-257.

5 TK judgment of 8 September 2008, Case no. K 5/07.
} 
axiological foundations of the Constitution that set a limit for laws that could be used to distort the historical truth in the future. ${ }^{6}$

Had the TK decided the case on substantive grounds, it would have noticed that the challenged provision could have become a tool to silence the public debate. Specifically, the law could prevent the truth about the degree of Polish participation in the war crimes against Jews, during the Second World War and soon afterwards, to be publicly aired. Yet, the TK decided not to take a stance on a matter of national controversy, contrary to the practice of constitutional courts which actively engage in shaping the national memory. ${ }^{7}$ Not only did the TK fail to emphasize the importance of the search of the truth theory of free speech, but also neglected the fact that the "free market of ideas" is often dominated by majorities, whose political and economic power enables them to define the truth of the day. In these conditions, minority voices are not likely to be heard due to high costs of participation in this exchange. As a result, the idea that wins might be far from true but still be endorsed by most people.

In this paper we will address the main dangers of using law for historical assessment against a broader question of transitional justice. We view the law criminalising defamation of the Polish Nation as a symptom of the frustration, anxiety and defensiveness of those who wish to present Poland as a victim of foreign powers. Although the narrative of victimhood may be effective in instilling the feeling of national identity in a new constitutional regime, it is definitely problematic when the protection of this image becomes a legislative aim. Such an emotional and value-laden aim is often conceived as more pressing than individual rights and freedoms, and it is likely to distort their balance of in the proportionality analysis. In consequence, victimhood distorts the rights talk.

Taking Poland as a case-study, we inquire whether a similar approach to national memory is replicated in other states of Central and Eastern Europe (CEE), which also wish to control and manage a historical discourse. If so, a hypothesis may be articulated that post-communist states, affected by a double trauma of Nazi and Communist crimes, are a special case in a global phenomenon of transitional justice, and must be treated

\footnotetext{
${ }^{6}$ For an account of the marketplace theory of free speech see: John Milton, Areopagitica (1644); John Stuart Mill, On Liberty (1859) and Justice Oliver Wendell Holmes's dissent in Abrams v US (1919). According to Mill, the ultimate truth may even not be attained: however, a perpetual exchange of ideas in a search of truth is a second best option that rational societies can choose. A similar conviction was shared by Justice Oliver Wendell Holmes who argued that "the ultimate good desired is better reached by free trade in ideas - that the best test of truth is the power of thought to get itself accepted in the competition of the market, and that truth is the only ground upon which their wishes safely can be carried out".

7 This position of self-restraint could be explained as the reaction to the criticism towards activist courts undertaking the risk of overturning laws which displace parliamentary choices in transitional conditions of weak civil society and political system. Wojciech Sadurski, 'Transitional Constitutionalism: Simplistic and Fancy Theories' in Adam Czarnota, Martin Krygier and Wojciech Sadurski (eds), Rethinking the Rule of Law after Communism (Budapest: CEU Press 2005) 9-24. Following this argument, activism is not required in a consolidated democracy. Yet, the question remains whether the postCommunist countries are to be considered as such.
} 
accordingly. Additionally, the question arises why such law emerged 20 years after democratic revolutions had taken place in this region. ${ }^{8}$

On the one hand, there are a number of countries from the CEE region which provide topical examples of legislative attempts to sanction a particular interpretation of past events. Twenty years after the end of the Balkan war, Croatia and Serbia accused each other of genocide and war crimes that were allegedly committed between 1991 and 1995. Although the International Court of Justice found that the intentional element of genocide is lacking in this case, and rejected the mutual accusation of the Serbian and Croatian governments, ${ }^{9}$ it is likely that each party to this controversy will not change the dominant rhetoric about what had actually happened.

On the other hand, similar tendencies to preserve a specific interpretation of history are present in other states affected by a dramatic past, armed conflicts or years of totalitarian regime. In particular, in countries where a new constitutional order emerged not as a result of a revolution, but an agreed transition, like Spain, the conditions of the pact (or the Round Table agreement) are likely to be challenged in the future. ${ }^{10} \mathrm{In}$ 2007, the Spanish Congress of Deputies introduced a new so-called "memory law" - the Law of Historic Memory. ${ }^{11}$ The law, which was vividly discussed and gave rise to many controversies, prohibited the organisation of political events at the Valley of the Fallen and Franco's burial place and ordered the removal of Francoist symbols from public buildings and spaces (with exceptions granted for artistic or architectural reasons and to religious sites). The authors and supporters of the provision emphasised that its aim was the recognition of the victims of political, religious and ideological violence on both sides of the Spanish Civil War and of Franco's regime. ${ }^{12}$ However, it seems obvious from the merits of the law that it was thought of as a tool for praising and aiding Franco's victims and condemning his allies. Thus, its opponents treat the law as a violation of the Spanish 'Pact of

\footnotetext{
${ }^{8}$ One possible answer to this question is that the transition in many post-Communist states has not yet been completed. As the example of Hungary shows the transition that came in waves often proves to be incomplete and in such contexts "the quest to achieve justice for the past continues". Renáta Uitz, 'The Incomplete Transition in Hungary' in Nico Wouters (ed), Transitional Justice and Memory in Europe (1945-2013) (Cambridge: Intersentia 2014) 289-325.

${ }^{9}$ ICJ Judgment of 3 February 2015 - Application of the Convention on the Prevention and Punishment of the Crime of Genocide (Croatia $v$ Serbia).

10 Michel Rosenfeld, The Identity of the Constitutional Subject: Selfhood, Citizenship, Culture and Community (London: Routledge 2010) 197.

11 The Law to recognise and broaden rights and to establish measures in favour of those who suffered persecution or violence during the Civil War and the Dictatorship, B.O.E. 2007, 52/2007, English translation <http://www.derechos.org/nizkor/espana/doc/lmheng.html> accessed 16 December 2014. ${ }^{12}$ Vincent Druliolle, 'Democracy Captured by its Imaginary: The Transition as Memory and Discourses of Constitutionalism in Spain’ (2008) 17 Social and Legal Studies 75-92.
} 
Forgetting' that was legally incorporated into the 1977 Amnesty Law, ${ }^{13}$ and accuse it of being "[a]ccusatory rather than reconciliatory". ${ }^{14}$

\section{POLAND'S HISTORY AND THE "ETERNAL VICTIM" SYNDROME}

In order to fully describe the background to the adoption of the challenged law in Poland (and its incorporation into the Criminal Code), a caveat is necessary. One needs to refer to events which, at the time dominated the political discourse and became a hotbed of nationwide debate, or rather controversy that in fact radically divided Poles and awoke many negative national sentiments. However, these events and the following debate concerned only the imputation of the involvement in Nazi crimes. Importantly, until then, there had been no serious public debate about various attitudes of Poles towards Jews in the years of the Second World War and in the years following its end. The reasons for this situation are complex. What is certain is that this gap in the national memory had an official justification - the government of Poland did not ally with the Nazi regime, thus the guilt for collaboration could be only attributed to individual members of the Nation. Additionally, in the pre-war period the "Polish Nation" was ethnically much more diverse than now, thus the guilt for the participation in Nazi crimes was often attributed to other ethnic groups.

It is also important to note that the case of Communist crimes is different because the Communist regime was formally established in Poland under the Constitution of 1952 and lasted until 1989. Thus, the involvement of the government and individuals in Communist crimes was never disputed; rather the central question after the fall of Communism was who was a secret agent or a collaborator. Notably, the participation of members of the Polish Nation in Communist crimes was officially recognized by the legislator that established the Institute of National Remembrance (Instytut Pamięci Narodowej, 'IPN'), and adopted a number of transitional measures doing justice to victims of the regime and punishing the perpetrators. In both cases of transition from and to democracy - after the Second World War and after the fall of Communism - there was a strong temptation to present the image of Poland as pure and innocent - a victim of historical circumstances dictated and imposed by foreign rulers. ${ }^{15}$ Thus, the external

\footnotetext{
${ }^{13}$ The Spanish Amnesty Law has itself been subject to controversies and sharp criticism, (i.e. by the UN human rights bodies), which stress that under international human rights law there must be no statute of limitations for crimes against humanity, as are contained in the 1977 law. See the UN position: <http://www.trust.org/alertnet/news/spain-must-liftamnesty-for-franco-era-crimes-un> accessed 16 December 2014.

${ }^{14}$ Daniel E Stofleth, Memory Politics in Spain: The Law of Historical Memory and the Politics of the Dead (International Association of Genocide Scholars database), <http://www.genocidescholars.org/sites/default/files/document $\% 09 \% 5$ Bcurrentpage \%3A1\%5D/documents/IAGS\%202011\%20Daniel\%20Stofleth.pdf> accessed 16 December 2014.

15 i.e. Act of 18 December 1998 on the Institute of National Remembrance - Commission for Prosecution of Crimes against the Polish Nation (Ustawa z dnia 18 grudnia $1998 \mathrm{r}$. o Instytucie Pamięci Narodowej - Komisji Ścigania Zbrodni przeciwko Narodowi Polskiemu), Official Journal 1998, no. 150, item 1016.
} 
influence of the Nazis and Soviet Communists was emphasized in order to mobilize society and establish a new sense of common identity.

Clearly, the truth about the involvement of the Polish Nation in Nazi crimes is more problematic. Recently, Klaus Bachmann provided a detailed explanation of this case, underlying the geopolitical shift of the Polish borders to the West and the meaning of "collaboration" in post-war Poland. ${ }^{16}$ As he has observed,

"First, as far as collaborators with the German occupier were concerned, the Polish authorities could only prosecute, judge and punish perpetrators of whom they could get hold in the territory of post-war Poland". ${ }^{17}$

"During the Stalinist period, mere participation in anti-communist or anti-Stalinist organizations during the war became a reason for prosecution (and often enough for extralegal executions), despite the fact that all anti-Soviet clandestine movements had actually also conspired or fought against the German occupier". ${ }^{18}$

Further, the notion of "collaboration" was also used by the anti-Soviet groups (representing radical right and anti-Semitic views) to address both the collaboration with the Soviet authorities and the protection of Jews and other national and ethnic minorities from pogroms. ${ }^{19}$

Characteristically, the term "collaboration" in Poland under occupation was highly politicised and did not mean "resistance" against the occupier. Rather, it reflected the difficult reality of Polish guerillas facing two occupiers and at times taking different sides (with or against the German troops, the Red Army, Soviet or Ukrainian guerillas). In consequence, the post-war authorities prosecuted not only war crimes, but also national treason, which enabled them to also accuse of betrayal people who did not belong to the "Polish" Nation such as Wehrmacht officers, citizens of the Third Reich, Germans from Germany's former eastern territories, etc. In this context, "collaboration" was restricted to relatively few ethnic Poles who were Gestapo informers or members of the Navy-Blue Police. ${ }^{20}$ Consequently, the Polish Nation remained, in fact, blameless and the few Poles who did collaborate with the occupier could be compared to rotten apples in a healthy barrel. ${ }^{21}$

Yet, this image of the Polish Nation as a victim of the Nazi regime, and the particular understanding of the Polish collaboration, has been seriously challenged by the publication by Jan Tomasz Gross, an eminent historian of Princeton University, for the first time in 2001. In his book Neighbors: The Destruction of the Jewish Community in Jedwabne, Poland, he told the story of the burning of the Jedwabne Jews in a barn by their

\footnotetext{
${ }^{16}$ Klaus Bachmann, 'The Polish Paradox: Transition from and To Democracy' in Nico Wouters (ed), Transitional Justice and Memory in Europe (1945-2013) (Cambridge: Intersentia 2014) 326.

17 ibid 328.

18 ibid 329.

19 ibid.

${ }^{20}$ Officially, the Polish Police of the General Government (German: Polnische Polizei im Generalgouvernement) - police forces created by Nazi Germany on the territory of the General Government.

${ }^{21}$ ibid 339.
} 
Polish neighbors in July $1941 .{ }^{22}$ In the discussion about the attitude of ethnic Poles towards the Holocaust and the Polish Jewry during the war, some commentators denied the truth of this historical account and refused to admit it. This was the truth about incidents of "blackmail, extortion, denunciation, betrayal, and plunder of the living and the dead" 23 carried out by Poles against Jews in many places in Poland during the Second World War and in its aftermath. ${ }^{24}$ Moreover, Jan Tomasz Gross and other intellectuals, or even film directors who undertake the subject of Polish antiSemitism and violence against the Jews are publicly accused of "antiPolishness". 25

Ultimately, as rightly observed by Klaus Bachmann, the controversy stirred by Gross's publications indicates

"a retrospective societal value shift from the very inclusive, patriotic memory, whose roots can be traced back to the sixties, to a more exclusive, critical post-materialist memory, which began to develop in Western Europe during the seventies". ${ }^{26}$

Yet, in his view, this shift concerns only a relatively small group of people corresponding to the number of respondents who answer in opinion polls that there are matters in Polish history of which Poles should be ashamed. Subsequent publications of J. T. Gross on Polish anti-Semitism also provoked very hostile reactions. In this emotional climate some right-wing, populist politicians advanced a program of the "defence of the honour of Poland and the Poles" and the provision in the Criminal Code penalizing the "defamation of the Polish Nation", later called by some observers "lex Gross", was part of this program. ${ }^{27}$

The drafters of this law explained the need to introduce it in the following way:

"(it) is necessary since very often we are witnesses on the international arena of untrue accusations addressed against both the

\footnotetext{
22 ibid

${ }^{23}$ Martin Krygier, Lifting the Burden of the Past (keynote address for symposium Why Poland? Facing the Demons of Polish-Jewish History, Melbourne, Australia, 28 November 2012).

${ }^{24}$ The truth is still being unveiled by eminent Polish historians who study the history of the Holocaust on Polish lands, including Barbara Engelking, Jan Grabowski and Jacek Leociak from the Polish Centre for Holocaust Research. See e.g. Jan Grabowski, Rescue for Money: 'Paid Helpers' in Poland, 1939-1945 (Warsaw: Search and Research Series, 2008) 13; Barbara Engelking, Jacek Leociak, Warsaw Ghetto. The Guide through the Perished City (New Haven: Yale University Press 2009).

${ }^{25}$ According to Janine P Holc, "Anti-Polishness is represented as a systemic denigration of Polish ethnic identity, a discoursive formula as ready-made as that of anti-Semitism. One element in the formula is the charge of anti-Semitism itself. According to this logic, any description of anti-Semitism in Poland is a stand-in for the repetition of a stereotype, the stereotype of the ethnic Pole as an anti-Semite", Janine P Holc, "Memory Contested: Jewish and Catholic Views of Auschwitz in Present-Day Poland' in Robert Blobaum (ed), Antisemitism and its Opponents in Modern Poland (New York: Cornell University Press 2005) 323.

${ }^{26}$ Klaus Bachmann (n 16) 339.

${ }^{27}$ Case comment by Ireneusz C Kamiński, available at: $<$ http://prawaczlowieka.edu.pl/index.php?dzial=komentarze \&komentarz=640bacfb48aefac 1f91028c01603e5c78d4f63ca-c0> accessed 16 December 2014.
} 
Polish nation and Polish citizens about the alleged assistance or collaboration with criminal Nazi and Communist regimes". ${ }^{28}$

They referred to the need to defend the "historical truth" against distortions and misinterpretations without noticing or rather without wanting to notice that the provision in question would contribute to such distortion of the past much more than any commentaries of American press or history professors. Clearly, the proposed provision was also intended to punish the use of such terms as "Polish concentration camps" with reference to German Nazi concentration camps built by the occupant on the Polish territory, offering a mechanism against obvious lies and intentional misinterpretations.

However, this motivation is not an excuse for incorporation into the legal order of a provision which allows for the sanctioning of the historical truth and preserving false social ideas about the past. As rightly noted by the leading Polish constitutionalist, Wojciech Sadurski, the driving force behind this unfortunate provision was "to demonstrate by its authors their patriotic zeal and out-bidding their political rivals". ${ }^{29}$ His views are shared by Uladzislau Belavusau who reminds us that:

"[f]or societies in which national victimhood is still explicitly articulated and which were deprived of the opportunity to discuss their history (...), the criminalisation of alternative modes of constructing history immediately brings a chilling effect on the advancement of historical truth (...)". ${ }^{30}$

Viewed from a comparative perspective, Poland is not alone in the camp of "victims" of foreign powers. As noticed by Renata Uitz, Nazi and Communist regimes in Hungary are usually portrayed as "foreign imposed" or "foreign inspired" and these popular narratives help to downplay "Hungarian" responsibility for the events even though the Hungarian authorities in the Horthy and Szálasi era often "took an active role in perpetrating atrocities and implementing repressive measures with pain striking efficiency on their own, often without direct pressure from outside". ${ }^{31}$ The clear difference between Poland and Hungary in their roles of "victims" concerns the lack of official involvement in the Nazi regime on the side of the Polish authorities ${ }^{32}$ but rather the individual involvement of Poles who either collaborated with the oppressors or voluntarily committed crimes against their Jewish neighbours. Thus, in the context of transition the critical point for the legislator is to understand that the idea of a nation as a monolithic entity is an archaic notion as a nation in a post-totalitarian state comprises both victims and perpetrators, war heroes, passive bystanders and collaborators.

\footnotetext{
${ }^{28}$ Parliamentary Records, 5th term, no. 334.

${ }^{29}$ Wojciech Sadurski, Liberat po przejściach (Poznań: Sens 2007) 96.

${ }^{30}$ Uladzislau Belavusau, Freedom of Speech. Importing European and US Constitutional Models in Transitional Democracies (London: Routledge 2013) 200.

${ }^{31}$ Renáta Uitz (n 8).

32 In 1946 Jan Kott argued "We are rightly proud of not having our own Hácha or Quisling, that there was no single Polish party which collaborated with the occupier and that even among our pre-war fascists, only a few believed in the civilizing mission of the German people. There is no such expression in Polish as 'collaborationism' because there was no collaboration. There were only traitors and special courts, which dealt with them" cited after: Klaus Bachmann (n 16) 338.
} 


\section{SHAPING NATIONAL MEMORY BY CRIMINAL LAWS}

Over the last century Poland had been marked with wars and totalitarian regimes. Reborn in 1989, the democratic state had to cope with the aftermath of the past and engage many legal instruments in the effort. The process of constitution-making required not only dealing with the past, but also responding to new extra-constitutional norms stemming from the European Convention of Human Rights and the European Union. One of the crucial aspects of breaking with the legacy of the Communist state involved establishing the rule of law and providing redress for human rights abuses through the means of decommunization, lustration and access to secret service files, property restitution, as well as the rehabilitation of victims and punishment of perpetrators. Although some of these measures have primarily an economic function, they ultimately help to restore citizens' sense of dignity and justice, revitalize ethnic, religious and national identities in a society whose moral bonds were destroyed during the Communist rule, ${ }^{33}$ and build social trust. However, the intentions and the consequences of transitional measures may not always be judged as being positive.

Like in other countries in CEE, transitional measures in Poland were adopted over a period of time in result of a dialogue between the political branches - the Parliament and the frequently changing government coalitions, and the courts - the Constitutional Tribunal and the European Court of Human Rights. In 2006 the Parliament adopted another change to the Act on the disclosure of information about documents of state security organs from the years 1944-1990 and their contents (the Lustration Act). ${ }^{34}$ The law amended several statutes, including the Criminal Code by incorporating an new provision (Article 132a), which stated that

"anyone who publicly defames the Polish Nation of involvement, organization or liability for Communist or Nazi crimes is guilty of a felony and on conviction is subject to imprisonment not exceeding 3 years".

Article 132a of the Criminal Code applied to both Polish citizens and any other person of a different nationality, irrespective of the law in force in the jurisdiction where the crime was committed. Consequently, under this provision, a prison sentence of three years could have been imposed on both a Polish historian in Warsaw who disclosed cases of Poles' collaborating with the Soviet occupant and an American journalist in New York who published an article about the "Polish death camps" existing during World War II.

\footnotetext{
33 Grażyna Skapska, 'Restitutive Justice, Rule of Law and Constitutional Dilemmas' in Adam Czarnota, Martin Krygier \& Wojciech Sadurski (n 7) 213.

${ }^{34}$ For a detailed study of the amendment, see Ireneusz C Kamiński 'Kontrowersje prawne wokół przestępstwa polegającego na pomawianiu narodu o popełnienie zbrodni’ (2010) VIII Problemy Współczesnego Prawa Międzynarodowego, Europejskiego i Porównawczego 5-34.
} 
From a purely legal perspective, this provision carries a number of defects which should not be tolerated in criminal law; because of the gravity of sanctions it should be clear and precise. Both the term "Polish Nation" and the category of "Communist crimes" and "Nazi crimes" are not legally defined. Thus, it is contrary to the principle of the specificity of legal provisions, which requires that the language of criminal law sets the limits to prohibited actions in the most precise way. As a result, an "intuitive" interpretation of the provision in question could lead to the conclusion that any accusation of involvement, organization or liability of the Polish Nation for Communist or Nazi crimes satisfies the criteria of this offence. In a criminal trial " $\mathrm{t}] \mathrm{he}$ judicial authority must prove all the circumstances which condition criminal liability". ${ }^{35}$ Thus, to achieve this aim, it seems that courts would apply Article 132a of the Criminal Code in a very restrictive way. Last, but not least, the actual possibilities of bringing criminal charges against any person, regardless of her nationality and the place where the offence is committed, would be limited.

The legal ambiguity of the provision (as well as its ideological character) was strongly criticized by Wojciech Sadurski who argued that many historical theories and conceptions could be prohibited on this ground:

"Would, for example, public statements about the range of the collaboration of Poles with Nazis be qualified as examples of illegal accusations of Polish Nation of involvement in Nazi crimes? A Nation, after all, is not 'acting' in itself; only the individuals act. At which point do the statements about numerous Polish citizens collaborating with the Nazis become equivalent to the accusation of the Nation as a whole? What sorts of caveats will render historians immune to criminal liability; will it be enough if they declare that the cases of collaboration were by and large isolated? Or that, in the case of Communism, a majority of people opposed the system while only a few collaborated, those few being non-representative of the Nation as a whole?". ${ }^{36}$

These and other questions lay in the background of the constitutional challenge raised by the Ombudsman (Rzecznik Praw Obywatelskich, literally 'Spokesman for Citizens' Rights') in the application for the constitutional review. In essence, the Ombudsman questioned the excessive penalization of the imputation of the involvement of the Polish Nation in Nazi and Communist crimes. The Ombudsman claimed that the penal law protection of dignity and the good name of the Polish Nation imposes disproportionate limitations on the constitutional freedom of speech and academic research. Additionally, the Ombudsman argued that the personal scope of this provision is unclear due to the ambiguous meaning of the term "Polish Nation". In the dominant scholarly opinion, the Polish Nation means all citizens of the Republic of Poland. Following this interpretation, the Prosecutor General argued that the Polish Nation understood as "all citizens of the Republic of Poland" did not take part in Nazi and Communist crimes, or organized them, thus it may not be liable for such crimes. In the opinion

\footnotetext{
${ }^{35}$ For an in-depth analysis of the purely legal controversies concerning the provision see Mateusz Woiński, 'Przestępstwo tzw. pomówienia Narodu Polskiego (de lege derogata)' (2009) no. 2 Państwo i Prawo 76-89

${ }^{36}$ Wojciech Sadurski (n 29) 97.
} 
of the Prosecutor General, this term refers to all citizens, rather than individual members of the Nation. Yet, following this logic, the reason for adopting such law is missing. Further, the Commissioner noticed that the involvement of members of the Polish Nation in Nazi and Communist crimes has been officially recognized by the legislator adopting the law on the Institute of National Remembrance, declaring as void judgments against persons persecuted for their activities on behalf of an independent Polish state, regulating the status of combatants and victims of repressions of war and post-war, and imposing sanctions for Nazi criminals guilty of the murder and abuse of civilians and the traitors of the Polish Nation.

Significantly, the new Prosecutor General (appointed in 2007) concurred with the Commissioner, changing the position taken by his predecessor (appointed in 2005 by the former right-wing government), and claimed that the impugned provision is not necessary in the context of the existing protection against the defamation of the Polish Nation (not related to the imputation of the involvement in Nazi or Communist crimes) ${ }^{37}$ and the insulting of individuals based on their nationality, ethnic and racial origin, religion or worldview. ${ }^{38}$ Thus, dignity and the good name of the Polish Nation is already protected under the Criminal Code, and the term "Polish Nation" has never been constitutionally challenged for the lack of clarity. ${ }^{39}$

Similarly, the Sejm (the lower chamber of the Parliament), represented in the proceedings before the Constitutional Tribunal, expressed the opinion that the challenged provision is unconstitutional. It is important to note that, between the date when the Parliament adopted the law and the hearing of the case by the Tribunal, a new government coalition won the parliamentary majority. Thus, in this case, the provision under review was an "orphan" whom none of authorities represented in the proceedings tried to defend. Even if only for this reason, it is unfortunate that the decision focussed on the procedural aspect of the legislative process rather than on constitutional axiology and individual freedoms. The problem relating to the mode of the legislative process was indicated by the Ombudsman during the oral hearing. Yet, this argument pointing out that the Sejm did not intend to amend the Criminal Code, but the Act on the Institute of the National Remembrance occupied most of the Tribunal's attention.

As a result, the TK found that the amendment to the draft law (incorporating Article 132a to the Criminal Code) as proposed by the Senate (the Upper Chamber of the Parliament) exceeded the permissible scope of Senate's amendments. According to the constitutional orthodoxy, the Senate may not propose amendments to law adopted by the Sejm that is not substantively identical with the subject matter deliberated by the Sejm. The Constitutional Tribunal agreed with this view. However, it did so taking a very subjective position on the original intent of the drafters that was "to punish the defamation of the Polish Nation through the expanded

\footnotetext{
${ }^{37}$ Article 133 of the Criminal Code.

${ }^{38}$ ibid, article 257.

${ }^{39}$ Piotr Kardas, Kodeks karny. Część szczególna. Komentarz (Warszawa: Beck 2002) 134135.
} 
competence of the Prosecutor of the Institute of the National Remembrance". Relying on this interpretation, the TK further noted that the Senate's amendment did not serve the same aim because it delegated the power to prosecute for defamation of the Polish Nation to 'regular' prosecutors. In this way, as one of the dissenting judges (Wojciech Hermeliński) noted, the Tribunal reformulated the legislative aim of the challenged provision, and the constitutional challenge put forward by the Commissioner.

\section{INTERNATIONAL HUMAN RIGHTS STANDARDS AND THE PRESERVATION OF THE NATIONAL MEMORY}

The European Court of Human Rights (hereinafter 'ECHR') often ruled in cases in which that the way the state regulated permissible ways of interpretation or reference to the past was the main element and bone of contention. While the ECHR is usually very prudent and sensitive to the historical context of internal regulations and their interpretation by national courts, it often favours the position of governments which refer to the Nazi and fascist past than to Stalinism and Communism. ${ }^{40}$ The Court is often more willing to admit that states are right in restricting rights and freedoms of individuals and groups when their actions relate to Nazism and emphasizes that the danger connected with the reactivation of such views is much greater and more serious than in case of attempts to reawaken the demons of Communism. ${ }^{41}$ The margin of appreciation is usually more generously at work in the former category of cases than in the latter category which means that, for instance, Germany, Austria or France are given more latitude to cope coercively with their pasts than, say, Hungary, Latvia or Poland. Thus, it must be stated that there is a clear contrast between the Court's treatment of "post-Communist" cases and the same Court's earlier treatment of highly equivalent "post-Nazi" cases. Although some of the Court's arguments for these "double standards" are understandable and convincing, it could be recommended that the Court accord less "leniency" to post-Communist states when they legislate about conduct and expression related to their own history ${ }^{42}$.

Violation by the provision in question of the standards of the protection of the freedom of speech and scientific research, i.e. standards protected by the Polish Constitution and standards developed within the European and universal systems of human rights protection, is yet another problem. These doubts have been aptly addressed in the application to the Constitutional Court. Should the provision be retained in the Polish legal

\footnotetext{
40 For an excellent analysis of the Court's attitude towards such cases see James A Sweeney, The European Court of Human Rights in the Post-Cold War Era. Universality in Transition (London: Routledge 2013).

${ }^{41}$ Vajnai v Hungary, no. 33629/06, judgment of 8 July 2008. The dictum of the Court has been confirmed in the case Fratanoló v. Hungary, no. 29459/10, judgment of 3 November 2011

${ }^{42}$ For a detailed consideration of such "double standards" see Aleksandra GliszczyńskaGrabias, 'Stalinism and Communism equals or versus Nazism? Central and Eastern European Unwholesome Legacy in ECtHR' (2016) 30.1 East European Politics and Societies.
} 
order, possibly resulting in further convictions for the "defamation of the Polish nation", the practice would be definitely questioned at the forum of the most important monitoring bodies of the human rights protection. Any critical follower of the case-law of the ECHR would have difficulty in finding there a permission to restrict a historical debate in such a drastic way as was done by the provision of the Polish criminal code in question, except perhaps cases related to the Holocaust denial, ${ }^{43}$ which, however, is an entirely different category.

At the same time, in its General Comment on the right to free speech embodied in article 19 of the International Covenant on Civil and Political Rights the UN Human Rights Committee explicitly stated that:

"Laws that penalize the expression of opinions about historical facts are incompatible with the obligations that the Covenant imposes on States parties in relation to the respect for freedom of opinion and expression. The Covenant does not permit general prohibition of expressions of an erroneous opinion or an incorrect interpretation of past events. (...)". ${ }^{44}$

Thus, even if the troublesome provision passed the constitutionality test in Poland, it would surely be found as violating free speech standards in Strasburg or Geneva.

Most certainly, in a hypothetical case against Poland the European Court of Human Rights would have found the breach of freedom of speech with regard to individual sanctions imposed for the defamation of the Polish Nation. ${ }^{45}$ As rightly pointed out by Ireneusz C. Kamiński,

"[a]n unrestricted debate about the history of the country in which different points of view and hypotheses should be admitted and where it is not possible to reach certainty is of vital importance for the [ECHR]". ${ }^{46}$

The ECHR would probably note the many controversies and threats to the freedom of speech and scientific research in the provision of the criminal code which could serve as the basis for imposing imprisonment sentences on historians who reveal historical truth.

\footnotetext{
43 See Aleksandra Gliszczyńska-Grabias, 'Penalizing Holocaust Denial - a View from Europe' in Charles Asher Small (ed), Global Antisemitism - A Crisis of Modernity (Brill: Leiden 2013).

${ }^{44}$ General comment no. 34, CCPR/C/GC/34, para. 49.

45 The district prosecutor for Kraków-Krowodrza decided to refuse the initiation of investigation on the matter of public insult and accusation of the Polish Nation that took place in Cracow and in other towns of involvement, organization or liability for Nazi crimes in the book by Jan Tomasz Gross, Strach. Antysemityzm tuż po wojnie. Historia moralnej zapaści (Kraków: Znak 2008).

${ }^{46}$ Case comment by IC Kamiński

$<$ http://prawaczlowieka.edu.pl/index.php?dzial=komentarze \&komentarz=640bacfb48aefac

1f91028c01603e5c78d4f63ca-c0> accessed 14 December 2014.
} 


\section{CONCLUSIONS}

Memory is never constant and immutable. To the contrary, it is subject to continuous reinterpretation, and is necessarily linked to present concerns and ideas about the future. As Walter Benjamin pointed out,

"[m]emory is not an instrument for exploring the past but its theatre.

It is the medium of past experience, as the ground is the medium in which dead cities lie interred". 47

However, if memory is misused for the pure purpose of gaining political and ideological advantage, its changeability and impermanence can turn out to be a dangerous trap.

The discussed provision of the Polish Criminal Code, apart from its vagueness and ambiguity, was a result of an obvious intention to influence the historical debate and social perception of historical events. The adoption of this provision was also a completely failed attempt to "save" Poland and the Poles from the consequences of gross ignorance by people and media using such terms as "Polish concentration camps" with reference to German Nazi concentration camps built in Poland by the occupier. Viewed in this light, Article 132a of the Criminal Code was an example of an inadmissible establishment of a historical dogma by means of legal measures. ${ }^{48}$ It was also in complete contradiction to the ideas and spirit of the famous Appeal of Blois, in which the members of the Liberty for History (Liberté pour l'Histoire) Association had proclaimed:

"History must not be a slave to contemporary politics nor can it be written on the command of competing memories. In a free state, no political authority has the right to define historical truth and to restrain the freedom of the historian with the threat of penal sanctions $[\ldots] "{ }^{49}$

When evaluating the position taken by the Polish Constitutional Court it must be remembered that the pragmatic decision to declare the provision unconstitutional on purely formal grounds served to avoid further ideological and political controversies, and led to a "happy end", i.e. the eradication of bad law. Yet, other constitutional courts in post-Communist countries did express their views on socially and historically sensitive issues, and explained in their case law which of transitional justice instruments are permitted or even desired in a democratic state governed by the principle of the rule of law, and which are contrary to this principle. This category of cases, indeed, belongs to the most difficult and controversial issues with which those constitutional courts had to cope. The fundamental dilemma they faced was how to reconcile, on the one hand, a commitment to the principle of constitutional continuity (requiring, as it does, a presumption in favour of constitutionality of the old laws, even if the presumption is relatively weak and easily rebuttable) and the general principles of the rule of law (including non-retroactivity and respect for

\footnotetext{
${ }^{47}$ Walter Benjamin, One-Way Street and Other Writings (London: Verso Books 1979) 314.

${ }^{48}$ See René Rémond, History and the Law, (Études no. 4046, 2006).

${ }^{49}$ Blois Appeal, 'Liberté pour l'Histoire'

$<$ http://www.lph-

asso.fr/index.php?option=com_content $\&$ view=article $\&$ id=47\&Itemid=14\&lang=en>

accessed 16 December 2014.
} 
vested rights) with, on the other hand, the principles of justice, the policy of breaking with the unwholesome past, and respect to the dignity and expectations of victims of the Communist regime.

Perhaps of all the matters belonging to this area the most difficult was the question of statutes of limitations of criminal liability for politically motivated crimes, and the approaches taken by the Czech and the Hungarian Constitutional Courts illustrate two different ways of balancing continuity with justice, rule of law with expectations of a "new beginning". While the Czech Court gave priority to a version of the "natural law" approach, deeming old constitutional commitments as not worthy of respect, ${ }^{50}$ the Hungarian Court has taken an opposite path, assuming that a new democratic state cannot begin its life with a violation of (what the Court saw as) the universal principles of the rule of law. ${ }^{51}$ This dilemma pervaded many other issues belonging to the "dealing with the past" category and handled by constitutional courts in the Central and East Europe in recent years. ${ }^{52}$ All these issues which haunt new democracies in the region inevitably became translated into the language of constitutionalism. What was lost in translation, though, was the underlining dilemma of retribution versus forgiveness: concepts better suited to religion or morality than to a rigid constitutional analysis.

Yet, the case discussed in this paper poses another serious question: whether the "dignity", "honour" or "good name" of a nation should be subject to legal protection, and in particular whether it can be a legitimate aim of the legislation in countries which emerge from totalitarianism. The Polish state with its complex and tragic history, marked as it is by decades of foreign rule and weakened by the rule of two totalitarian regimes in the twentieth century, having regained its longed for freedom in 1989, has a full right and even a duty to demand the protection of the memory of its difficult past. However, at the same time, it cannot, using legal instruments, escape from responsibility for and awareness of the crimes and vile acts committed in the past not against Poles but by Poles. These events are part of the actual history of the Polish state and nation, and may be even more important than manifestations of Polish heroism and strength.

\section{Bibliography}

Books:

Belavusau U, Freedom of Speech. Importing European and US Constitutional Models in Transitional Democracies (Routledge 2013). Benjamin W, One-Way Street and Other Writings (New Left Books 1979).

\footnotetext{
${ }^{50}$ Decision 19/93 of the Constitutional Court of Czech Republic no. 9/01 of 21 December 1993.

${ }^{51}$ Decision of the Constitutional Court of Hungary no. 11/1992 of 5 March 1992.

52 See Wojciech Sadurski, Rights Before Courts: A Study of Constitutional Courts in Postcommunist States of Central and Eastern Europe (Dordrecht Heidelberg London New York: Springer 2014, $2^{\text {nd }}$ ed.) 329-382.
} 
Engelking B, Leociak J, Warsaw Ghetto. The Guide through the Perished City (Yale University Press 2009).

Grabowski J, Rescue for Money: 'Paid Helpers' in Poland, 19391945 (Search and Research Series 2008).

Gross JT, Strach. Antysemityzm tuż po wojnie. Historia moralnej zapaści (Znak 2008).

Kardas P, Kodeks karny. Czesść szczególna. Komentarz (Wydawnictwo C.H.Beck 2002).

Mill JS, On Liberty (1859).

Milton J, Areopagitica (1644).

Rémond R, History and the Law (Études no. 4046, 2006).

Rosenfeld M, The Identity of the Constitutional Subject: Selfhood, Citizenship, Culture and Community (Routledge 2010).

Sadurski W, Liberał po przejściach (Sens 2007).

Sadurski W, Rights Before Courts: A Study of Constitutional Courts in Postcommunist States of Central and Eastern Europe (Springer 2014, $2^{\text {nd }}$ ed.).

Sweeney JA, The European Court of Human Rights in the Post-Cold War Era. Universality in Transition (Routledge 2013).

Chapters in edited books:

Bachmann K, 'The Polish Paradox: Transition from and To Democracy' in N Wouters (ed), Transitional Justice and Memory in Europe (1945-2013) (Intersentia 2014).

Holc JP, 'Memory Contested: Jewish and Catholic Views of Auschwitz in Present-Day Poland' in R Blobaum (ed), Antisemitism and its Opponents in Modern Poland (Cornell University Press 2005).

Gliszczyńska-Grabias A, 'Penalizing Holocaust Denial - a View from Europe' in Small ChA (ed), Global Antisemitism - A Crisis of Modernity (Brill 2013).

Sadurski W, 'Transitional Constitutionalism: Simplistic and Fancy Theories' in A Czarnota, M Krygier and W Sadurski (eds), Rethinking the Rule of Law after Communism (CEU Press 2005).

Scheppele KL, 'Constitutional Interpretation after Regimes of Horror' in S Karstedt (ed) Legal Institutions and Collective Memories (Hart Publishing 2009).

Skapska G, 'Restitutive Justice, Rule of Law and Constitutional Dilemmas' in A Czarnota, M Krygier \& W Sadurski (eds), Rethinking the Rule of Law after Communism (CEU Press 2005).

Uitz R, 'The Incomplete Transition in Hungary' in N Wouters (ed), Transitional Justice and Memory in Europe (1945-2013) (Intersentia 2014).

Articles:

Druliolle V, 'Democracy Captured by its Imaginary: The Transition as Memory and Discourses of Constitutionalism in Spain' (2008) 17 Social and Legal Studies.

Gliszczyńska-Grabias A, 'Stalinism and Communism equals or versus Nazism? Central and Eastern European Unwholesome Legacy in ECtHR' (2016) 30.1 East European Politics and Societies. 
Kamiński IC, 'Kontrowersje prawne wokół przestępstwa polegającego na pomawianiu narodu o popełnienie zbrodni' (2010) VIII Problemy Współczesnego Prawa Międzynarodowego, Europejskiego i Porównawczego.

Krygier M, Lifting the Burden of the Past, keynote address for symposium Why Poland? Facing the Demons of Polish-Jewish History, Melbourne, Australia, 28 November 2012.

Michnik A, 'Żydowski problem z pamięcią (Jewish problem with the memory)' Gazeta Wyborcza, Warszawa, 28 April 2013.

Woiński M, 'Przestępstwo tzw. pomówienia Narodu Polskiego (de lege derogata)’ (2009) no. 2 Państwo i Prawo.

Digital sources:

Appeal B, 'Liberté pour 1'Histoire', <http://www.lphasso.fr/index.php?option $=$ com_content $\&$ view $=$ article $\& i d=47 \&$ Itemid $=14 \& 1$ ang=en $>$ accessed 16 December 2014.

Kamiński IC, case comment available at:

$<$ http://prawaczlowieka.edu.pl/index.php?dzial=komentarze\&komen $\operatorname{tarz}=640 \mathrm{bacfb} 48 \mathrm{aefac} 1 \mathrm{f} 91028 \mathrm{c} 01603 \mathrm{e} 5 \mathrm{c} 78 \mathrm{~d} 4 \mathrm{f} 63 \mathrm{ca}-\mathrm{c} 0>$ last accessed 16 December 2014.

Stofleth DE, 'Memory Politics in Spain: The Law of Historical Memory and the Politics of the Dead', available at International Association of Genocide Scholars database $<$ http://www.genocidescholars.org/sites/default/files/document $\% 09 \% 5 \mathrm{Bcurr}$ entpage $\% 3 A 1 \% 5$ D/documents/IAGS\%202011\%20Danie1\%20Stofleth.pdf> accessed 16 December 2014.

'UN position on the Spanish Amnesty Law', available at $<$ http://www.trust.org/alertnet/news/spain-must-lift-amnesty-for-franco-eracrimes-un> accessed 16 December 2014. 